\title{
Moderasi Beragama di Tengah Cyber-Religion dan COVID-19: (Studi terhadap Mahasiswa Fakultas
}

\section{Ushuluddin IAIN Kudus)}

\author{
Akhmad Mundakir \\ Kementerian Agama Kudus, Indonesia \\ amd64kirasya@gmail.com
}

\begin{abstract}
This article examines religious phenomena on social media. The rise of speakers on social media gives a new coulor to modern religious issues, as it relates to the issue of religious moderation. because the media is often used to invite and teach religious teachings in a right and rigid so that it becomes a cyber-religion that can not be accounted for its authority. This reality received many responses from the community, including students of the Faculty of Ushuluddin IAIN Kudus. This article is a qualitative study that reveals the perception of Students of Faculty Ushuluddin on religious moderation in the midst of the media and pandemic. This article concludes that the religious cyber phenomenon is a consequence of the rise of religious preachers on social media. Amid covid-19, religious lectures also contain pandemic themes that are sometimes provocative and construction.
\end{abstract}

Keywords: covid-19, media, cyber-religion, religious moderation 


\begin{abstract}
Abstrak
Artikel ini mengkaji tentang fenomena keagamaan di media sosial. Maraknya penceramah di media sosial memberikan warna baru dalam isu keagamaan modern, karena berkaitan dengan isu moderasi beragama. pasalnya, media sering digunakan untuk mengajak dan mengajarakan ajaran agama secara rigit dan kaku, sehingga menjadi cyber-religion yang tidak dapat dipertanggungjawabkan otoritasnya. Realitas tersebut mendapatkan banyak tanggapan dari masyarakat, termasuk mahasiswa Fakultas Ushuluddin IAIN Kudus. Artikel ini kajian kualitatif yang mengungkap persepsi mahasiswa Fakultasu Ushuluddin atas moderasi beragama di tengah gencarnya media dan pandemi. Artikel ini menyimpulkan bahwa fenomena siber keagamaan merupakan konsekuensi atas maraknya para penceramaha keagamaan di media sosial. Di tengah covid-19, ceramah keagamaan juga memuat tema-tema pandemi yang terkadang bersifat provokasi dan konstruksi.
\end{abstract}

Kata kunci: covid-19, modeasi beragama, media, siber-keagamaan

\title{
Pendahuluan
}

Pandemi COVID-19 (Corona Virus Disease-19) merupakan wabah yang terjadi hampir di seluruh belahan dunia termasuk Indonesia yang masuk sejak Maret 2020 lalu dan telah membawa dampak besar, sehingga mengalami perubahan yang signifikan, mulai dari kesehatan, pendidikan, perdagangan, agama, dan sektor lainnya. Fenomena tersebut juga mempunyai dampak pada perbedaan pandangan yang beragam terhadap pandemi COVID-19 ini. Perbedaan tersebut muncul disebabkan oleh berbagai faktor yang mempengaruhi, salah satunya faktor eksternal yaitu media. Media menjadi salah satu wadah yang menyebarkan informasi kepada khalayak ramai yang tidak hanya sebatas media cetak, tetapi media elektronik. Media elektronik yang diwakili oleh media sosial lebih diminati sebagian manusia. Bahkan media sosial sudah menjadi wadah bagi berbagai bidang termasuk dakwah (Arifin, Fuady, \& Kuswarno, 2017, hal. 90).

Media sosial menjadi tempat bagi berkembangnya dakwah karena kemudahan bagi siapapun untuk mengakses internet serta tanpa terbatas oleh ruang. Media sosial memberikan kemudahan bagi semua manusia, termasuk anak-anak, dewasa maupun orang tua. Kesibukan masing-masing orang membuat media sosial menjadi alternatif utama. Informasi yang dibagikan melalui media sosial lebih ringkas, baik yang bersifat keagamaan, ekonomi dan budaya, sehingga cenderung disukai sebagai sumber pengetahuan. Adapun problematikanya ialah kompetensi dan otoritas yang terdapat dalam meida tidak dapat dipertanggungjawabkan, karena tidak semua informasi yang terdapat dalam media menampilkan kecapakan dan keahlian. Permasalah ini menjadi semakin rumit, ketiak pesan yang disampaikan dipahami secara rigit dan kaku. 
Kekakuan memahami agama dalam kondisi yang majemuk adalah kurang tepat, pasalnya pesan yang diterima dari media harus dipahami secara komprehensif tidak hanya dibaca dan dipahami hanyat teksnya saja. Kekakuan dalam memahami ajaran agama akan semakin menjadi permasalah bersama ketika hadir di tengah pendami COVID-19. Pasalnya, akan ada banyak motif, termasuk isu keagaman sebagai pemecah belah umat. Maka bagi penulis moderasi beragama perlu disosialisasikan ke masyarakat dan sebelum target sosialisasi tersebut ke masyarakat setidaknya dimulai dari lembaga pendidikan terutama Perguruan Tinggi Agama Islam Negeri. Sosialisasi ini sebagai bentuk pemahaman atas kuatnya arus radikalisme beragama di media sosial.

Moderasi agama sebagai paradigma berpikir, bersikap dan bertindak yang dipelopori oleh Kementerian Agama harus disambut sebagai acuan dalam beragama, karena di tengah pluralitas beragama masih banyak dan tersebar radikalisme melalui sarana media informasi yang tidak terbatas. Hal ini, sangatlah memprihatinkan. Gerakan radikalisme di Indonesia disebabkan beberapa faktor yakni persoalan domestik dan konstelasi politik Indonesia yang dinilai menyudutkan kehidupan sosial politik umat Islam. Begitu juga dengan kalangan non muslim, harus menunjukkan ajaran yang menumbuhkan kesamaan dan kasih, seperti Agama Kristen yang harus mengajarakan kasih kepada umatnya (Widodo \& Karnawati, 2019, hal. 9).

Peran penyuluh agama sebagai kepanjangan tangan dari Kementerian Agama mempunyai peran penting dalam membangun moderasi beragama untuk mewujudkan kedamaian bangsa Indonesia. Maka pemahaman dan kesadaran multibudaya dengan cara menghargai perbedaan, kemajemukan, serta kemauan berinteraksi dengan siapapun secara adil sangat diperlukan dalam kehidupan multikultural. Sikap moderasi beragama diperlukan dengan mengakui adanya kelompok lain, menghormati perbedaan pendapat, tidak memaksakan kehendak melalui kekerasan dan bersikap toleran. Semua itu diperlukan sosialisasi serta kontribusi dari berbagai pihak seperti: pemerintah, tokoh masyarakat, dan para penyuluh agama untuk menumbuh kembangkan sikap moderasi beragama di masyarakat demi terwujudnya kedamaian dan keharmonisan (Akhmadi, 2019, hal. 45).

Edy Sutrisno (2019, hal. 345) menggagas dalam mengaktualisasikan moderasi beragama di masyarakat multikultural, maka langkah pertama yang dilakukan yakni menggunakan lembaga pendidikan sebagai laboratorium sebagai moderasi beragama. Penguatan Moderasi Beragama dalam kehidupan bermasyarakat harus bersamaan dengan pemahaman ajaran agama yang baik 
dan benar, sehingga agama tidak menjadi problematika di tengah masyarakat plural (Shihab, 2020). Gagasan tentang moderasi menjadi baik dan sebagai tawaran bagi masyarakat global ketika sudah kuat dalam kehidupan internal (Suharton et al., 2019).

Perkembangan media sosial dalam kehidupan plural keagamaan menjadi permasalah sendiri, pasalnya media sebagai alat untuk menyampaikan pesan agama, terkadang menjadi hakim dalam praktik keagamaan yang lain. Di tengah merebaknya COVID-19, media juga dimanfaatkan untuk memunculkan praktik keagamaan baru dan bahkan sebagai kontra narasi atas keagamaan lama, sehingga terjalin saling mengkritik dan menghakimi. Sehingga relevansi kajian ini terletak pada bagaimana media sosial sebagai alat dalam menyebarkan ajaran modeasi beragama dipahami dan disikapi oleh mahasiswa Fakultas Ushuluddin sebagai generasi atau agen moderasi Kementerian Agama.

\section{Metode Penelitian}

Metode Penelitian adalah cara peneliti untuk mendapatkan informasi dalam melakukan penelitian. Adapun jenis penelitian yang dilakukan penulis yakni field research atau penelitian lapangan. Karena mendapatkan data langsung yang dari lapangan. Jenis pendekatannya yakni kualitatif. Pendekatannya menggunakan kualitatif deskriptif karena menjelaskan persepsi mahasiswa terkait moderasi beragama di era pandemi. Sedangkan Subyek dalam penelitian ini yakni mahasiswa Fakultas Ushuluddin. Penelitian ini ditunjang oleh dua sumber data yakni primer dan sekunder. Sumber primer berasal dari hasil wawancara dan buku. Sedangkan sumber sekunder berasal dari penelitian sebelumnya yang masih berhubungan dengan riset penulis.

\section{Moderasi dalam Tinjuan Teoritis}

Moderasi berasal dari bahasa Latin moderatio, yang memiliki arti "sedang" atau tidak kekurangan maupun kelebihan. Sedangkan dalam bahasa Inggris istilah moderation cenderung mengarah pada pengertian non aligned (tidak berpihak). Istilah lainnya moderasi dalam bahasa Arab yakni "Wasathiyah" dengan padanan makna yakni tengah-tengah, adil dan berimbang. Menurut Qurasih Shihab (2020) istilah wasathiyah ataupun sejenisnya hendaknya memilih yang terbaik dan menunjukkan keadilan serta mengambil jalan tengah diantara pilihan ekstrem. 
Menurut Quraish Shihab (2020) Islam merupakan hakikat wasathiyah. Bahwa Islam mengajarkan moderasi dan penganutnya harus moderat. Moderat memiliki cakupan yang luas dalam beberapa hal yakni pandangan dan keyakinan, pemikiran dan perasaan, serta keterikatan. Penjelasan moderat tersebut bertumpu pada cendekiawan Mesir yakni Sayyid Quthub dalam menafsirkan QS. Al Baqarah (2): 143. Selain itu, moderasi memiliki makna untuk melakukan kebajikan yang dapat direalisasikan dengan cara mampu menahan amarah dan memaafkan kesalahan orang lain. Dalam menanggapi kesalahan orang lain atau perbedaan hendaknya bisa bersikap wasathiyah atau moderasi yang memiliki makna "adil" atau "yang terbaik" atau "pertengahan"(Abdullah, 2015).

Moderasi agama pada dasarnya adalah sebuah paradigma yang penting dalam pluralitas beragama untuk membangun kerukunan umat manusia di tengah kompliknya problematika masyarakat modern, seperti COVID-19. Banyaknya pemberitaan negatif dalam media dalam membenturkan ajaran agama dan COVID-19 menjadi kegamangan masyarakat umum, sehingga perlu menggunakan moderasi beragama sebagi platform menghadirkan media sosial (Muhtador, 2021, hal. 49). Realitas kegamangan akan menjadi kekerasan antar umat beragama ketiak tidak ditangani dengan baik dan pada akhirnya menjadi sumber perpecahan.

\section{Cyber-religion Generasi Milenial}

Sekitar 30 tahun yang lalu diskusi dan praktek keagamaan mulai muncul secara online. Pada awal tahun 1980-an, dua siswa dari Universitas Chicago mengembangkan sebuah buletin Board System (BBS) yang merupakan bagian dari forum virtual yang lebih besar yang disebut CommuniTree.'Buat agama Anda sendiri' adalah nama diskusi BBS yang dapat dianggap sebagai kegiatan keagamaan yang berorientasi secara online pertama. Rheingold dalam Virtullo (2016) adalah salah satu sarjana pertama yang mendokumentasikan bentuk primordial ini. Komunitas agama online, memberikan mereka nama 'komunitas virtual. Selama periode yang sama, diskusi keagamaan kelompok mulai muncul di web Usenet.

Istilah polisemik "Cyber-Religion" diciptakan baru-baru ini, dan mencakup berbagai realitas. Umumnya menunjuk cara-cara dimana agama berkembang dalam informasi baru teknologi, terutama internet dan, secara terbalik, bagaimana dunia keagamaan dipengaruhi oleh teknologisasi 
masyarakat dan budaya. Dalam arti yang lebih ketat, mungkin lebih berhubungan dengan kenyataan, itu digunakan untuk menggambarkan sistem keagamaan "virtual", baik yang didasarkan atau dibuat di dunia digital, (hampir) independen dari dunia fisik (Obadia, 2017).

Media elektronik, teknologi digital, komunikasi kecepatan tinggi, dan internet memiliki dampak yang menentukan pada organisasi keagamaan dan umat beragama. Kebanyakan pakar menganggap perubahan teknis ini membawa perubahan yang cepat dan masif, karena konsep "Revolusi digital." Jeremy Stolow (2010), percaya evolusi ini termasuk dalam rantai sejarah yang lebih dalam. Perubahan teknologi: munculnya pers, radio, dan televisi sebelumnya telah berkontribusi untuk mengubah agama, cara-cara organisasi keagamaan berkomunikasi, dan cara-cara orang percaya terhubung dan berpartisipasi dalam kehidupan ritual.

Beberapa kasus, "mediatization" telah menjadi Fitur utama dari globalisasi agama (Csordas 2009) melalui berbagi atau mendistribusikan ide, tema, simbol, gambar, video,dan hiperteks dan telah mencapai proses pengetahuan baru (Obadia, 2017). Cyber-religion, atau e-agama, agama digital, agama online, pertama ada melalui dan dibentuk oleh teknologi komunikasi. Forum-forum tentang ibadah, blog tentang agama, daftar buletin dari tokoh agama utama (termasuk Paus), menawarkan berbagai layanan (virtual berkat yang terhubung) melalui aplikasi smartphone dan laptop, dengan berbagai pemuka agama online yang menghasilkan praktik yang dimediasi, apakah ibadah,belajar, meditasi, doa ("berdoa online"), atau pengakuan dosa (Obadia, 2017).

Cyber-religion berbagi banyak fitur khas. Beberapa Kardinal membuka berbagai peluang: hubungan antara perorangan dan kelompok di luar lokasi geografis mereka; deterritorialisasi lembaga dan situs (Cyber-kuil atau CyberGereja); dari dematerialisasi organisasi keagamaan dan mode komitmen (Cyber-komunitas); Pendirian lahan baru bagi otoritas keagamaan teks (Hyper-scripturalism) dan simbol, evaluasi kritis, baik kolektif maupun perorangan; dan bahkan sakralisasi teknologi itu sendiri, bergerak dari agama internet sebagai agama. Ini evolusi umum mempengaruhi semua agama dari tradisi utama untuk kultus minoritas, sekte,gerakan keagamaan baru (NRMs) dan juga gerakan alternatif atau bijaksana, seperti okultisme, dan ilmu sihir, yang dimiliki juga diperluas secara online (Obadia, 2017). 
Sejak pengembangan World Wide Web, kehadiran keagamaan di Internet telah diperluas lebih jauh. Jelas bahwa agama terus menjadi komponen penting dari dunia maya. Sejumlah studi awal mengungkapkan hasil yang menarik mengenai keberadaan agama di internet. Pada 1996, studi Time Warner Company memperkirakan bahwa "ada tiga kali lebih banyak situs mengenai Allah dan spiritualitas daripada ada mengenai seks "(http: www. time. com/time/godcom/, di helland, 2007:957). Sebuah survei oleh Pew internet dan American Life Project di 2000 menemukan bahwa "21\% dari pengguna internet di Amerika Serikat mengakses konten online untuk melakukan beberapa bentuk kegiatan keagamaan "; Itu berarti 2.000 .000 orang menggunakan internet untuk tujuan keagamaan. Angka ini mengungkapkan bahwa "lebih banyak orang yang menggunakan internet untuk agama dan tujuan spiritual daripada yang menggunakan media untuk online perbankan dan layanan kencan online "(Larsen, 2000 di helland, 2007:957).

Satu tahun kemudian, di 2001, persentase meningkat menjadi 25\% dari internet pengguna, yang berarti bahwa lebih dari 3.000.000 orang sehari (Larsen, 2001). Hoover, Clark dan Rainie (2004) berpendapat bahwa "jumlah itu terus menerus meningkat dalam beberapa tahun terakhir bahwa di 2004, "64\% dari Amerika berkabel menggunakan internet untuk tujuan spiritual atau keagamaan" (Iqbal, 2016). Adakah yang salah dengan keberagamaan remaja Islam saat ini? Pertanyaan ini tentu tidak bermaksud menggugat kontain agama (Islam) di internet. Pertanyaan ini, mencoba untuk mengkritisi cara remaja muslim yang mulai terlena dengan cara keberagamaan yang instan dan lewat cara "ngaji" agama di internet. Profesor Adam Possamai, Direktur Penelitian di Sekolah Ilmu Sosial dan Psikologi, Universitas Western Sydney juga pernah merasakan kegelisahan yang sama terkait fenomena cyberreligion. Pernyataan Adam Possamai, tentang apa yang dimaksud agama saat ini berbeda dengan agama yang dipahami sebelumnya, tentu bukan tanpa alasan. Agama di zaman postmodern saat ini - suka atau tidak - merupakan bagian dari budaya konsumerisme (Hatta, 2019).

Satu hal yang pasti, menurut Adam Possamai, telah terjadi transformasi di dalam praktek agama saat ini. Praktek beragama menjadi sangat lentur dan bisa disesuaikan dengan karakter setiap media, termasuk smartphone. Agama tidak lagi dipahami seperti dahulu, dimana ritual keagamaan adalah sesuatu yang tidak layak untuk dipertanyakan, dibantah, atau dijalankan di luar pakem. Namun kini, dalam kehidupan masyarakat industri dan modern, tuntutan 
masyarakat menghendaki pada hal-hal yang instan, praktis, dan cepat, tak terkecuali dalam beragama (Hatta, 2019).

Salah satu alasan mengapa "ngaji" agama di internet banyak dilakukan remaja muslim adalah karena kepraktisan. Praktis identik dengan mudah dan cepat. Berbeda dengan praktik beragama konvensional yang membutuhkan waktu lebih lama. Lain halnya dengan "ngaji" lewat media sosial. Tausiyah ulama atau ustad bisa disimak lewat smathphone dan bisa memilih sendiri topik apa yang dicari dan disukai. Bahkan dikalangan muslim, ada pula yang menunaikan solat sunnah tarawih dengan mengikuti ritual solat tarawih dari Masjidil Haram Makkah yang berjarak waktu lebih awal 4 jam, lewat siaran langsung televisi atau smartphone (Hatta, 2019). Melalui smartphone orang bisa lebih mudah terkoneksi dengan internet dan dapat mencari informasi tentang agama apapun dan.bisa menyebarkan ajaran agama, maupun menerima informasi keagamaan. Melalui smartphone mereka bisa merepresentasikan identitas religiusnya masing-masing (Hatta, 2019).

Memanfaatkan media sosial untuk tujuan membentuk identitas diri sebagai muslim, awalnya boleh jadi terkesan "norak" atau kampungan. Namun belakangan, tampilan identitas ini justru menjadi kebanggaan. Demikian halnya dengan upaya memanfaatkan media sosial dengan tujuan menimba ilmu agama Islam, boleh jadi merupakan fenomena lucu dan sarkarme. Karena selama ini internet, dalam persepsi yang liar, merupakan teknologi yang merusak iman. Selama ini Internet identik dengan hal yang profan, sedangkan agama identik dengan hal yang sakral. Selain tidak punya otoritas, citra internet juga terkesan "jorok" dengan maraknya konten pornografi, sehingga membuat banyak muslim menghindari internet. Namun asumsi tersebut kini mulai bergeser. Informasi tentang Islam justru marak di internet. Ditambah dengan sifat pengguna Internet yang terbuka, bebas dan berbagi, menyebabkan konten keislaman cepat menyebar di Internet. Mulai dari pemahaman tentang tauhid, fiqih, hadiss, tafsir Alquran, dan cara ibadah,termasuk informasi jihad (Hatta, 2019).

Cyber-religion ini menjadi sebuah tantangan bagi semua agama, tidak hanya Islam. Dan untuk seluruh generasi milenial di seluruh dunia ini. Namun dalam peristiwa generasi milenial di Indonesia, hal ini menjadi sebuah tantangan tersendiri sebab fenomena cyber-religion ini justru menjadi sarana kaum jihadis untuk menyebarluaskan ajarannya. Berdasarkan hal ini, diperlukan satu formula yang tepat dalam menyikapi fenomena ini. 


\section{Dialog Multikultural}

Menurut M. Amin Abdullah bahwa dialog berbeda dengan kompetisi. Dialog bukanlah tempat untuk mendapatkan kemenangan atas yang lain. Dialog menjadi salah satu wadah bagi masyarakat majemuk. Sebelum terjadi dialog, hendaknya para peserta dialog memahami etika berdialog. Berikut etika berdialog antar umat beragama yang perlu diperhatikan (Abdullah, 2015): pertama, setiap peserta dialog semuanya setara dan sederajat. Kedua, tidak ada yang lebih tinggi, superior, lebih mendominasi, lebih menentukan, lebih hebat ataupun lebih berkuasa. Ketiga, saling mendengar uraian dan penjelasan yang disampaikan patner dialog sebagai kemampuan utama. Keempat, memposisikan diri sebagai teman yang seperjalanan dalam mencari hakikat hidup dan bukan sebagai hakim seolah mengadili terdakwa.

Dialog bagi masyarakat majemuk dilakukan dengan harapan dapat saling mengenal, memahami dan mengerti, menghormati dan mengasihi, bekerjasama dan membangun solidaritas kemanusiaan, serta hidup berdampingan secara damai dan harmoni antar umat beragama yang berbeda keimanan dan kepercayaan. Hal pertama yang dapat memicu terjadinya konflik dalam masyarakat majemuk yakni karena tidak saling mengenal (Abdullah, 2015). Masyarakat yang tidak saling mengenal dalam menjalani hubungan akan terasa kaku, sehingga hubungan tersebut akan kurang baik dan harmonis. Setelah itu akan menumbuhkan rasa curiga dan mudah berburuk sangka serta riskan adanya isu-isu. Jadi kebutuhan dasar masyarakat majemuk salah satunya saling mengenal baik secara sosial, kultural maupun teologi.

Ada harapan dialog yang kedua yakni masyarakat dapat memiliki kemampuan saling memahami atau mutual understanding. Sikap saling memahami dapat direalisasikan dengan cara menerima orang lain tanpa syarat. Hal tersebut dapat terealisasi apabila telah mengenal terlebih dahulu. Batasan mutual understanding yakni tidak menggerus identitas diri (Abdullah, 2015). Harapan dialog ketiga yakni saling mengasihi. Pada tahap ini dialog mengajak umat manusia untuk tidak mudah membenci, berburuk sangka atau melakukan tindakan deksriminatif terhadap yang berbeda. Saling mengasihi tidak hanya berlaku bagi umat intern, tetapi secara luas baik trans ras, trans suku, trans kelompok, trans agama dan kepercayaan lainnya. Bahkan dalam hadis telah disebutkan "man lam yarham al nas lam yarhamillah", artinya barang siapa belum dapat mencintai sesama manusia, dia tidak akan dapat mencintai Tuhan). 
Dalam hadis tersebut secara tidak langsung mengajak manusia untuk mencintai semua orang pada umumnya tanpa membeda-bedakan (Abdullah, 2015). Dialog yang terakhir yakni membangun solidaritas. Solidaritas menjadi kunci utama perdamaian sejati bagi masyarakat majemuk. Pada dasarnya baik umat Islam atau agama lain yang memiliki solidaritas tidak akan tega dan sampai hati apabila teman sekampung, sebangsa, dan senegara walau berbeda agama mengalami kesusahan, kesulitan, tekanan dan penindasan oleh siapapun. Menurut Tasya (2021) solidaritas menjadi alternatif yang dibutuhkan masyarakat majemuk untuk bersatu menyelesaikan berbagai macam konflik yang jauh lebih utama untuk kemaslahatan semua umat manusia.

\section{Persepsi Mahasiswa terhadap Moderasi Beragama di Era Pandemi}

Persepsi mahasiswa terkait agama ialah kepercayaan bagi umat yang memeluknya (Janah, 2021a). Agama merupakan identitas sekaligus pedoman (Tassya Elvitasari, 2021) yang mengatur tatanan kehidupan (Anggraeni, 2021a) untuk menjadi mahluk yang penuh dengan cinta kasih (Krismayanti, 2021a) walaupun berbeda-beda (Abdusyarof, 2021a) guna menjadi penyelemat untuk meraih ridho Tuhan. Menurut Tasya Elvitasari (2021) moderasi beragama adalah cara pandang seseorang dalam beragama secara moderat, tidak ekstrem kanan maupun kiri (Krismayanti, 2021c). Sedangkan bagi Praditya Anggraini moderasi beragama dapat ditunjukkan melalui sikap tawazun (berkeseimbangan), i'tidal (lurus dan tegas), tasamuh (toleransi), musawah (egaliter), syura (musyawarah), ishlah (reformasi), aulawiyah (mendahulukan yang prioritas), tathawwur wa ibtikar (dinamis dan inovatif) (Abdusyarof, 2021b). Walaupun orang yang beragama dengan cara pandang moderasi tidak berlebihan, tetapi juga tidak ingkar serta memperhatikan keadilan dan kemanusiaan (Luthfillah, 2021).

Moderasi menjadi salah satu alternatif dan bentuk dari dinamisnya ajaran agama pada masyarakat majemuk sesuai perkembangan zaman. Moderasi juga dapat menciptakan suasana harmonis diantara umat beragama (Janah, 2021b). Suasana tersebut wujud dari saling menghargainya diantara umat beragama (Fitriyani, 2017, hal. 151). Selain itu moderasi sangat erat dengan Islam dan hal itu ditunjukkan dengan sikap menghargai tradisi. Pandemi menjadi kondisi khusus yang mana semua aktivitas peribadatan dibatasi guna memtuskan penyebaran wabah, tetapi dalam hal ini agama memiliki peran sebagai umat yang mematuhi perintah seorang pemimpin untuk melakukan aktivitas peribadatan di rumah. Walaupun begitu tidak 
menghalangi bagi seorang umat untuk tetap dengan Tuhan. Peran penting media sosial dalam gerakan moderasi beragama di Era Pandemi adalah dengan cara memanfaatkan media sosial sebagai sesuatu yang memberikan informasiinformasi yang positif, menciptakan sikap toleransi yang baik (Ayuni, 2021a).

Media sosial di era pandemi ini sangat penting dan berguna dalam mencari informasi agar masyarakat tidak terjerumus pada ajaran agama yang ekstrim (Magfiroh, 2021; Reknawati, 2021). Dengan itu, maka kita perlu mengikuti, memilah, memiliki akun-akun yang jelas dan berkampanye untuk mengajak gerakan moderasi beragama di media sosial pada era pandemi ini (Krismayanti, 2021b). Perbedaan memang selalu hadir dalam kehidupan dalam hal apapun. Penulis menemukan beberapa sikap yang hendaknya diterapkan saat berhadapan dengan perbedaan yang meliputi toleransi, saling menghargai, saling menghormati pilihannya, berbuat baik terhadap sesama, saling menyayangi dan mempererat tali persaudaraan tanpa mengolok-olok perbedaan yang ada.

Pengaplikasian pengetahuan terkait moderasi beragama dapat dilakukan saat seseorang memberikan respon terhadap orang lain yang menyinggung agamanya. Berdasarkan temuan penulis, ada beberapa respon terkait hal tersebut seperti diam, mengajak berdiskusi, sabar, memberikan masukan dengan cara ditegur, diingatkan, dinasehati dengan lembut (Ayuni, 2021b) atau bahkan memaafkan (Krismayanti, 2021d). Bahkan ada juga yang mengambil sikap untuk tidak tergesa-gesa merespon (Anggraeni, 2021b).

Selain itu, juga mencintai tanah air termasuk perintah agama. Mencintai bukan berarti semua sistem harus menganut agama tertentu justru pancasila sebagai lambang perjuangan semua umat beragama hingga berada pada tahap kemerdekaan, seperti yang diungkapkan oleh Muhammad Abdussyarof bahwa terhadap orang yang berbeda agama tetaplah berbuat baik dalam ranah kemanusiaan tetapi menjaga keyakinan dengan Tuhan(Abdusyarof, 2021b). Diyah Ayu Reknawati juga mengutarakan bahwa terhadap orang yang berbeda agama hendaknya saling menghargai, tidak mengolok-olok serta hidup berdampingan jauh lebih indah (Reknawati, 2021).

Sikap lainnya juga di utarakan oleh Nanda Ayuni bahwa terhadap agama yang beda hendaknya saling mempererat tali persaudaraan, serta saling menyayangi(Ayuni, 2021b). Berdasarkan data yang ditemukan penulis bahwa mahasiswa fakultas Ushuluddin telah menerapkan moderasi agama. Data yang ditemukan penulis sesuai dengan konsep moderasi atau wasathiyah yang 
diusung oleh Quraish Shihab (2020) bahwa orang yang paham moderasi akan berusaha melakukan kebajikan. Berbuat baik, sikap saling menghargai, tidak mengolok-ngolok yang beda termasuk mencerminkan kebajikan.

Selain itu juga berdasarkan teori dialog yang diusung oleh M. Amin Abdullah bahwa saling mengenal, saling memahami, saling mengasihi (Abdullah, 2015) juga tercermin pada mahasiswa fakultas ushuluddin seperti berbuat baik. Berbuat baik termasuk bagian dari saling mengenal, tidak mengolok-ngolok bagian dari seseorang yang telah memahami dan menyayangi serta mempererat tali persaudaraan termasuk bagian dari saling mengasihi dan solidaritas.

\section{Simpulan}

Mahasiswa Ushuluddin telah memahami moderasi beragama dan arti penting gerakan tersebut di Era Pandemi yang lebih rentan dalam penyebaran isu-isu yang sensitif. Hal tersebut dapat dilihat dari beberapa respon mahasiswa saat menghadapi orang yang berbeda agama dan pendapat. Respon yang ditunjukkan yakni berperilaku baik terhadap siapapun termasuk yang berbeda dengan mengedepankan kemanusiaan tanpa mencampuri urusan kepercayaan. Moderasi diperlukan supaya dalam beragama tidak ekstrimis agar mampu menciptakan solidaritas diantara umat beragama.

Media sosial sebagai media dapat menjadi gerakan siber-keagamaan baru yang dapat memberikan dampak positif dan negatif. Kesadaran atas penggunaan dan menyeleksi berita serta informasi keagamaan menjadi penting bagi lapisan masyarakat, khususnya mahasiswa Fakultas Ushuluddin sebagai, sebab tidak semua informasi agama menjadi benar dan dapat dijadikan sumber otoritas. Mahasiswa mempersepsikan fenomena agama di media sosial sebagai konsekuensi atas maraknya para penceramah dan tokoh agama yang sadar akan kuatnya media sebagai alat menyampaikan ajaran agama. 


\section{Referensi}

Abdullah, M. A. (2015). Sosiologi Dialog Antar Umat Beragama dalam Kemajemukan Negara-Bangsa. In Bunga Rampai sosiologi Agama: Teori, Metode dan Ranah Studi Ilmu Sosiologi Agama (hal. 107-113). Yogyakarta: Fakultas Ushuluddin dan Pemikiran Islam Universitas Islam Negeri Sunan Kalijaga.

Abdusyarof, M. (2021a). Pendapat Tentang Agama. Kudus.

Abdusyarof, M. (2021b). Pendapat Tentang Moderasi Beragama. Kudus: Google Form.

Akhmadi, A. (2019). Moderasi Beragama Dalam Keragaman Indonesia. Diklat Keagamaan, 13(2), 45-55.

Anggraeni, P. (2021a). Pendapat Tentang Agama. Kudus.

Anggraeni, P. (2021b). Respon Terhadap Orang Yang Menyinggung Agama. Kudus.

Arifin, H. S., Fuady, I., \& Kuswarno, E. (2017). Analisis Faktor Yang Mempengaruhi Persepsi Mahasiswa UNTIRTA Tehadap Keberadaan PERDA Syariah di Kota Serang. Junal Penelitian Komunikasi dan Opini Publik, 21, 88-101.

Ayuni, N. (2021a). Pendapat Tentang Peran Media Sosial dalam Gerakan Moderasi Beragama di Era Pandemi. Kudus.

Ayuni, N. (2021b). Pendapat Terhadap Orang Yang Berbeda Agama. Kudus.

Elvitasari, Tassya. (2021). Pendapat Tentang Agama. Kudus.

Elvitasari, Tasya. (2021). Pendapat Terkait Moderasi Beragama. Kudus: Google Form.

Fitriyani, Y. (2017). Analisis Pemanfaatan Berbagai Media Sosial Sebagai Sarana Penyebaran Informasi Bagi Masyarakat. Paradigma, 19.

George, C. (2013). Pelintiran Kebencian; Rekayasa ketersinggungan Agama dan Ancamannya bagi Demokrasi. Jakarta: Pusat Studi Agama dan Demokrasi (PUSAD).

Hatta, M. (2019). Media Sosial, Sumber keberagamaan Alternatif Anak Milenial Fenomena Cyberreligion Siswa SMA Negeri 6 Depok Jawa Barat. Dakwah: Jurnal Kajian Dakwah dan Kemasyarakatan. https://doi.org/10.15408/dakwah.v22i1.12044

Iqbal, A. M. (2016). WHEN RELIGION MEETS THE INTERNET (Cyber-Religion and the Secularization Thesis). Jurnal Komunikasi Islam, 1. https://doi.org/DOI: https://doi.org/10.15642/jki.2016.6.1.1-28

Janah, S. N. (2021a). Pendapat Terkait Agama. Kudus.

Janah, S. N. (2021b). Pendapat Terkait Moderasi Beragama. Kudus: Google Form.

Krismayanti, N. (2021a). Pendapat Tentang Agama. Kudus.

Krismayanti, N. (2021b). Pendapat Tentang Peran Media Sosial sebagai Gerakan Moderasi Beragama di Era Pandemi. Kudus.

Krismayanti, N. (2021c). Pendapat Terkait Moderasi Beragama. Kudus: Google Form.

Krismayanti, N. (2021d). Respon Terhadap Orang Yang Menyinggung Agama. Kudus. 
Luthfillah, M. 'Aniq. (2021). Pendapat Tentang Moderasi Beragama. Kudus: Google Form.

Magfiroh, K. Z. (2021). Pendapat Tentang Moderasi Beragama. Kudus.

Muhtador, M. (2021). Memahami Moderasi Beragama sebagai Paradima Perilaku Masyarakat Plural di Tengah Pandemi. In Pandemi dalam Kacamata Agama dan Filsafat. Cirebon: Nusa Litera Inspirasi.

Ningrum, D. J., Suryadi, \& Wardhana, D. E. C. (2018). Kajian Ujaran Kebencian di Media Sosial. Jurnal Ilmiah Korpus, 2(3), 241-1252. https://doi.org/https://doi.org/10.33369/jik.v2i3.6779

Obadia, L. (2017). Cyber-Religion. In B. S. Turner (Ed.), The Wiley Blackwell Encyclopedia of Social Theory. https://doi.org/https://doi.org/10.1002/9781118430873

Reknawati, D. A. (2021). Peran Media Sosial Bagi Gerakan Moderasi Beragama. Kudus.

Shihab, M. Q. (2020). Wasathiyyah; Wawasan Islam tentang Moderasi Beragama. Jakarta: Lentera Hati.

Suharton, B., Saidurrahman, Mujahidin, A., Nizar, M. S., Muhibbin, Hamid, I. al, ... Mudzakir. (2019). Moderasi Beragama dari Indonesia untuk Dunia. Yogyakarta: LKiS.

Sutrisno, E. (2019). Aktualisasi Moderasi Beragama. Bimas Islam, 12, 323-348.

Vitullo, H. A. C. \& A. (2016). Assessing changes in the study of religious communities in digital religion studiesNo Title. Church, Communication, and Culture, 1. https://doi.org/https://doi.org/10.1080/23753234.2016.1181301

Widodo, P., \& Karnawati. (2019). Moderasi Agama dan Pemahaman Radikalisme di Indonesia. Teologi dan Pendidikan Agama Kristen, 15(2), 9-14. 